\title{
KAJIAN MOTIF BENDA TEKNOLOGIS PADA GAPURA KOMPLEKS MAKAM SUNAN DRAJAT DAN CANDI TEGAWANGI
}

\author{
Angga Fajar Ramadhan ${ }^{1}$, Warih Handayaningrum ${ }^{2}$ \\ ${ }^{1}$ Program Studi Pendidikan Seni Budaya, Pascasarjana, Universitas Negeri Surabaya \\ Email: angga.90kaotan@gmail.com \\ ${ }^{2}$ Program Studi Pendidikan Seni Budaya, Pascasarjana, Universitas Negeri Surabaya \\ Email: warihhandayaningrum@unesa.ac.id
}

Masuk : 20-12-2020, revisi: 04-04-2021, diterima untuk diterbitkan : 24-04-2021

\begin{abstract}
Ancient buildings are closely related to the long history of the past. The architectural style of the building and its decorative motifs have a distinctive shape in accordance with the spirit of the era of its creation. The idea of creating styles and forms of decoration took the forms of the surrounding nature and the philosophy of the patrons and local rulers. Some of the many decorative motifs that exist, there are motifs that come from religious values. In addition, the various forms of motifs that exist also have similar forms. The similarities in the shape of these motifs are found in the shape of the motifs of technological objects in the gate of Sunan Drajat's tomb which has Islamic breath with one of the relief panels in Tegawangi Temple which has Hindu-Buddhist breaths. The purpose of this research is to describe the idea of the creation of the two forms of motifs, the factors that cause the similarity of the motive forms and reveal the meaning of the two forms of motifs. This research method uses descriptive qualitative methodology. The approach used in this study uses a historical approach, to reveal the meaning used semiotic theory. The data collection technique is done by conducting literature study, observation, interviews and documentation. The data obtained is then reduced, displayed and analyzed. The results showed that the basic idea of creating the motifs of technological objects in the wooden gate of the tomb of Sunan Drajat and Candi Tegawangi took inspiration from the sacred buildings that had been built previously, namely the form of mosques and temples. The factors causing the similarity of form, namely: (a) cultural interaction; (b) adaptation of the form of the motive; (c) acculturation; and (d) marriage or the establishment of family relationships. The meaning of the two motives is the relationship between humans and the transcendent.
\end{abstract}

Keywords: Motif of technological objects, Sunan Drajat, Candi Tegawangi

\begin{abstract}
ABSTRAK
Bangunan purbakala lekat kaitannya dengan sejarah panjang dari masa lalu. Gaya arsitektur bangunan dan motif ragam hiasnya memiliki bentuk yang khas sesuai dengan semangat zaman penciptaannya. Ide penciptaan gaya dan bentuk ragam hias mengambil bentuk-bentuk alam sekitar dan falsafah dari patron maupun penguasa setempat. Sekian dari banyak motif ragam hias yang ada, terdapat motif yang bersumber dari nilai religi. Selain itu, dari berbagai bentuk motif yang ada juga memiliki kemiripan bentuk. Adapun kemiripan bentuk motif tersebut dijumpai pada bentuk motif benda teknologis di gapura makam Sunan Drajat yang bernafaskan Islam dengan salah satu panel relief di Candi Tegawangi yang bernafaskan Hindu-Buddha. Tujuan penelitian ini adalah untuk mendeskripsikan ide penciptaan kedua bentuk motif, faktor-faktor penyebab terjadinya kemiripan bentuk motif dan mengungkap makna dari kedua bentuk motif. Metode penelitian ini menggunakan metodologi kualitatif deskriptif. Pendekatan yang digunakan dalam penelitian ini menggunakan pendekatan sejarah, untuk mengungkap makna digunakan teori semiotika. Adapun teknik pengumpulan data dilakukan dengan melakukan studi pustaka, observasi, wawancara dan dokumentasi. Data yang diperoleh kemudian direduksi, display dan dianalisis. Hasil penelitian menunjukkan ide dasar penciptaan motif benda teknologis pada gapura kayu makam Sunan Drajat dan Candi Tegawangi mengambil inspirasi bentuk dari bangunan suci yang telah dibangun sebelumnya, yaitu bentuk bangunan masjid dan candi. Faktor yang menjadi penyebab terjadinya keserupaan bentuk, yaitu: (a) interaksi budaya; (b) adaptasi bentuk motif; (c) akulturasi budaya; dan (d) perkawinan atau terjalinnya hubungan kekeluargaan. Adapun makna dari kedua motif tersebut yaitu hubungan antara manusia dengan yang transenden.
\end{abstract}

Kata Kunci: Motif benda teknologis, Sunan Drajat, Candi Tegawangi 


\section{PENDAHULUAN}

\section{Latar Belakang}

Benda seni merupakan salah satu produk kebudayaan dari suatu peradaban. Bentuknya yang mewujud, menjadikan benda seni dapat dilihat atau didengar atau keduanya sekaligus, bahkan dimanfaatkan kegunaannya oleh penikmatnya (Sumardjo, 2000). Bentuk kontemporer hadir dengan melepas pakem-pakem tradisi, namun masih menggunakan konsep atau akar-akar budaya tradisi sebagai ciri khas budaya Nusantara. Bentuk seni kontemporer mewujud dengan perupaan visual yang baru serta penuh dengan isu-isu yang terjadi pada masyarakat saat itu. Bentuk tradisi hadir dengan pakem-pakem tradisi secara turun-temurun dan memiliki nilai-nilai falsafah. Salah satu peninggalan kesejarahan yang bersifat kebendaan berupa bangunan kuno (bangunan suci). Sebuah bangunan yang keberadaannya mampu menembus dimensi ruang dan waktu yang cukup jauh hingga bertahan sampai dewasa ini. Penciptaan bangunan kuno akan selaras dengan kebutuhan keagamaan, penguasa ataupun masyarakat dan kondisi zamannya.

Unsur penting dalam setiap sistem religi, kepercayaan (agama), yaitu suatu emosi atau getaran jiwa yang sangat mendalam, yang disebabkan karena sikap kagum-terpesona terhadap hal-hal yang gaib dan keramat (Koentjaraningrat, 1987). Getaran jiwa yang dirasakan oleh penguasa ataupun masyarakat terhadap hal yang gaib diekspresikan dengan perwujudan simbol-simbol bangunan suci dan seni hias yang melekat pada konstruksi bangunannya. Manusia dengan kemampuannya menghasilkan simbol, secara tidak sadar mentransformasi sebuah benda atau bentuk menjadi simbol (mengisi benda-benda tersebut dengan signifikansi psikologis) (Jung, 2018). Adapun simbol-simbol tersebut memiliki nilai-nilai falsafah dan ajaran yang mendalam. Selain memiliki fungsi sebagai suatu simbol, ragam hias juga memiliki fungsi sebagai benda terapan dan fungsi estetis (Toekio, 2000; Raharjo, 2011). Ragam hias pada setiap wilayah mempunyai gaya bentuk yang khas. Bentuk yang khas tersebut oleh Van Der Hop dikelompokkan menjadi jenis-jenis ragam hias Nusantara berdasarkan motif hiasnya menjadi (a) motif geometris; (b) motif manusia; (c) motif binatang; (d) motif benda-benda alam; (e) motif benda-benda teknologis dan kaligrafi (dalam Sunaryo, 2009). Inspirasi perwujudan motif pada ragam hias diperoleh dari bentuk-bentuk benda yang ada dalam kehidupan sehari-hari ataupun bentuk benda alam yang telah digubah. Selain itu, inspirasi perwujudan motif juga diperoleh dari hasil khayalan atau imajinasi yang biasa disebut motif imajinatif (Senoprabowo et al., 2020).

Beragamnya bentuk motif yang ada, bentuk motif yang menarik dan lekat kaitannya dengan hasil cipta manusia berupa motif benda teknologis, Guntur (2004) menyebutnya sebagai motif artifisial. Motif benda teknologis merupakan bentuk motif dengan mengambil bentuk benda atau bangunan yang dibuat manusia, baik untuk keperluan hidup sehari-hari ataupun untuk keperluan ritual keagamaan. Salah satu motif benda teknologis yang berbentuk motif bangunan dapat ditemukan pada relief candi dengan aneka bentuknya. Ada yang berbentuk candi, rumah panggung, meru, gapura, dan lain-lain (Sunaryo, 2009). Banyaknya motif yang ada dari berbagai situs arkeologi, terdapat beberapa bentuk motif (benda teknologis) yang mempunyai keserupaan bentuk. Keserupaan bentuk motif tersebut dilatarbelakangi oleh dasar kepercayaan yang berbeda, hal ini dijumpai pada ragam hias yang menghiasi bangunan gapura paduraksa yang ada di kompleks makam Sunan Drajat dengan salah satu panel relief yang ada pada Candi Tegawangi.

Kompleks makam Sunan Drajat berada di Desa Drajat, Kecamatan Paciran, Kabupaten Lamongan, Jawa Timur. Kompleks makam tersebut merupakan makam dari salah satu sembilan Waliullah yang ada di Pulau Jawa. Sunan Drajat merupakan seorang Waliullah yang menyebarkan Agama Islam di Desa Drajat. Kompleks makam Sunan Drajat terdiri dari tujuh halaman, di mana halaman pertama terletak paling tinggi dan paling belakang serta sangat disakralkan. Halaman pertama, siti 
inggil (cungkup), yaitu makam Sunan Drajat dan istrinya. Halaman kedua adalah makam anak dan menantu. Halaman ketiga adalah makam anak cucu. Halaman keempat sampai ketujuh adalah anak cucu dan keturunannya (Tim Peneliti dan Penyusun Buku Sejarah Sunan Drajat, 1998). Adapun yang menarik dari setiap halaman adalah gapuranya. Gapura yang berada paling luar di sebelah selatan mempunyai bentuk ukiran yang indah dan menarik. Salah satu bentuk ukiran tersebut memiliki bentuk motif benda teknologis yang mirip dengan pahatan relief pada Candi Tegawangi. Candi Tegawangi merupakan candi yang terletak di Desa Tegowangi, Kecamatan Plemahan, Kabupaten Kediri, Jawa Timur. Candi Tegawangi merupakan tempat pendharmaan seorang raja Majapahit yang meninggal setelah 12 tahun dengan upacara Srada. Sekeliling tubuh candi dihiasi relief cerita Sudamala yang berjumlah 14 panel, yaitu 3 panel di sisi utara, 8 panel di sisi barat dan 3 panel sisi selatan. Cerita dari 14 panel relief tersebut berisi tentang pengruatan (pensucian) Dewi Durga dalam bentuk jelek dan jahat menjadi Dewi Uma dalam bentuk baik yang dilakukan oleh Sadewa, tokoh bungsu dalam cerita Pandawa (Mulyadi, 2018). Sekian banyak motif yang ada pada 14 panel tersebut, terdapat salah satu panel yang memiliki bentuk motif yang menyerupai bentuk motif yang ada di gapura makam Sunan Drajat. Dari fenomena tersebut dapat dirumuskan pertanyaan, yaitu: (a) bagaimana religi digunakan sebagai ide dasar penciptaan motif?; (b) apa faktor yang menjadi penyebab terjadinya keserupaan bentuk?; dan (c) bagaimana makna yang ada dari kedua bentuk motif tersebut?

\section{METODE PENELITIAN}

Penelitian ini merupakan penelitian kualitatif deskriptif. Penelitian ini menggunakan pendekatan sejarah, yaitu untuk mendeskripsikan faktor-faktor yang menjadi penyebab terjadinya kesamaan bentuk motif, serta mengungkap nilai religius yang menjadi ide dasar penciptaan motif dan menggunakan teori semiotika Rolland Barthes untuk mengungkap makna motif. Teknik pengumpulan data dilakukan dengan observasi pustaka, yaitu buku-buku, jurnal, sumber internet yang relevan dengan objek penelitian. Kemudian melakukan observasi lapangan dan wawancara dengan narasumber. Selama pengumpulan data, teknik yang digunakan adalah teknik dokumentasi, perekaman dan pencatatan data. Analisis data dilakukan dengan mereduksi, mendisplay dan memverifikasi data. Validasi data dilakukan dengan melakukan triangulasi data, yaitu menguji keabsahan data yang diperoleh dari hasil observasi dan wawancara yang telah dilakukan.

Langkah pertama dilakukan dengan menganalisis kedua bentuk motif berdasarkan konsep fungsi religi terhadap kebudayaan, yaitu untuk mengungkap ide dasar penciptaan motifnya. Kedua, melakukan analisis data pustaka untuk mencari data teoretis mengenai faktor-faktor penyebab terjadinya kemiripan bentuk berdasarkan konteks sejarah dari objek penelitian. Ketiga, menganalisis data lapangan yang telah diperoleh menggunakan teori semiotik Rolland Barthes, yaitu untuk melihat makna visual dari kedua bentuk motif. Rolland Barthes menyebutkan dua tingkatan dalam suatu tanda, yaitu perupaan bentuk (makna denotasi) dan isi dalam perupaan bentuk (makna konotasi). Makna denotasi bersifat langsung, dan dapat disebut sebagai gambaran dari suatu pertanda. Sedangkan makna konotasinya akan sedikit berbeda dan akan dihubungkan dengan kebudayaan yang tersirat di dalam pembungkusnya (tentang makna yang terkandung di dalamnya) (Berger, 2010).

\section{HASIL DAN PEMBAHASAN}

\section{Religi sebagai Dasar Penciptaan Motif}

Ragam hias merupakan salah satu kekayaan budaya yang mencerminkan kepribadian serta sebagai identitas kelompok masyarakat pendukungnya (Ilhaq, 2016). Penciptaan motif ragam hias yang bernafaskan religi merupakan hasil ekspresi, emosi atau getaran jiwa yang mendalam oleh penguasa ataupun kelompok masyarakat pendukungnya. Nilai religius yang ada di dalam ragam 
hias berisi korelasi kesadaran akan adanya hubungan manusia dengan manusia, manusia dengan alam, ataupun manusia dengan Tuhan. Fungsi religi terhadap kebudayaan memiliki fungsi inspirasi dan fungsi normatif (Wahid, 1985). Fungsi inspirasi menjadikan agama memiliki fungsi untuk menginspirasi serta menjadi panduan dan pedoman untuk merancang ide penciptaan suatu bentuk-bentuk motif dari ragam hias. Kemudian fungsi normatif sebagai pedoman yang berisi aturan-aturan dan nilai-nilai yang digunakan oleh masyarakat. Fungsi normatif dalam ragam hias berada pada motif yang disimbolkan dengan makna di dalamnya.

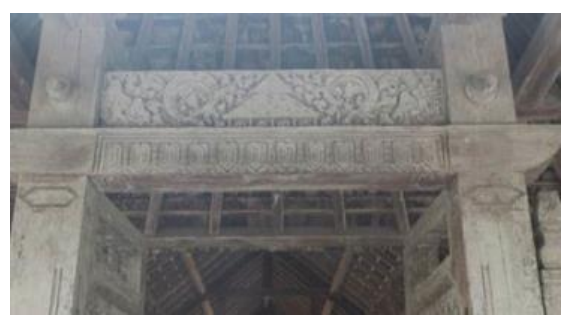

Gambar 1. Motif Benda Teknologis pada Gapura Paduraksa Kompleks Makam Sunan Drajat Sumber: Dokumentasi Pribadi 2020

Bentuk ukiran motif ragam hias yang ada pada gapura paduraksa makam Sunan Drajat menunjukkan bentuk motif flora, motif geometris dan motif benda teknologis. Fungsi inspirasi yang digunakan pada motif benda teknologis dapat dilihat pada bentuk motif bangunan. Motif tersebut mengambil inspirasi bentuk bangunan ibadah (masjid), di mana masjid merupakan salah satu bangunan arsitektur yang berciri khas Islam. Bentuk motif masjid mengalami stilasi bentuk dan digunakan sebagai motif utama. Ide penciptaan bentuk motif tersebut mengambil konsep bentuk masjid Demak. Masjid Agung Demak merupakan salah satu masjid tertua yang dibangun di Indonesia, khususnya di Pulau Jawa. Pembangunan masjid Agung Demak dilaksanakan tahun 1477-1479 atau tahun 1481 M (Ashadi, 2012). Pada masa penyebaran agama Islam di Pulau Jawa, Masjid Agung Demak memiliki nilai sejarah yang sangat penting, karena masjid ini digunakan sebagai tempat berkumpulnya para Wali Songo dalam menyebarkan agama Islam (Saraswati, 2015). Sunan Ampel juga disebut-sebut sebagai arsitek pembangunan masjid Agung Demak (Salam, 1974). Masjid Agung Demak kemudian menjadi prototipe dalam arsitektur masjid-masjid di Nusantara (Ashadi, 2012).

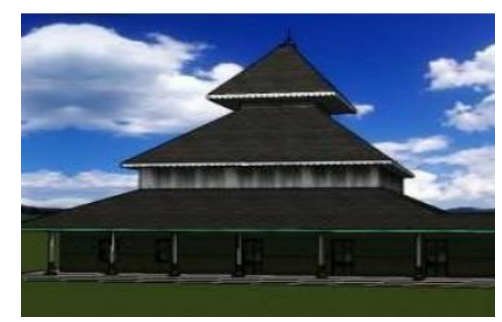

Gambar 2. Masjid Demak

Sumber: Dokumen (Kusyanto, 2020)

Gapura kayu dan cungkup makam Sunan Drajat yang ada saat ini merupakan karya pugar tahun $1609 \mathrm{M}$ yang dilakukan oleh pangeran Wanatirta. Pemugaran tersebut diyakini tidak menyimpang dari pola bangunan cungkup terdahulu (Tim Peneliti dan Penyusun Buku Sejarah Sunan Drajat, 1998). Pembuatan tersebut ditandai dengan candrasengkala yang berada pada lintel pintu masuk cungkup makam Sunan Drajat. Terukir angka tahun dengan bentuk candra sengkala mulyo guno ponco waktu (1531 S/1609 M) (Dasy, 2020). Dari tahun pembuatan gapura, masjid Agung Demak telah ada sebelum gapura kayu makam Sunan Drajat dibuat. Masjid Agung Demak telah digunakan 
oleh para Wali Songo untuk menyebarkan Agama Islam. Hal ini sesuai dengan hakikat kebudayaan itu sendiri, yaitu bersumber dari konsepnya yang abstrak berupa ide, gagasan, nilai, adat tata kelakuan, kemudian diaplikasikan dalam aktivitas serta sistem sosial, dan akhirnya diwujudkan dalam bentuk karya cipta (Tim Peneliti dan Penyusun Buku Sejarah Sunan Drajat, 1998). Fenomena tersebut menjadikan bentuk masjid Agung Demak yang berciri khas bangunan Islam di Nusantara digunakan sebagai ide penciptaan motif benda teknologis pada gapura kayu makam Sunan Drajat. Fungsi normatif dalam motif ragam hias tersebut menyimbolkan tempat ibadah, yaitu sebagai pengingat akan hubungan antara manusia dengan Allah. Penyatuan pencipta dan makhluknya (ibadah) yang baik akan memberikan ketenangan, kesejahteraan dan ketentraman dalam hidup.

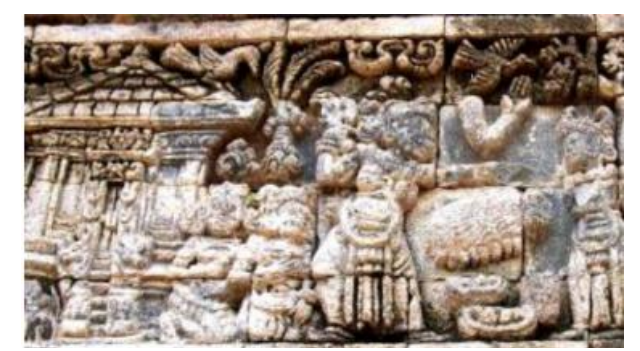

Gambar 3. Motif Benda Teknologis pada Salah Satu Relief di Candi Tegawangi Sumber: Dokumen Alifa, 2014 (dalam Adwina \& Ginanjar, 2019)

Bentuk ukiran motif ragam hias yang ada pada relief Candi Tegawangi menunjukkan bentuk motif flora, fauna, manusia dan benda teknologis. Fungsi inspirasi yang digunakan pada motif benda teknologis dapat dilihat pada bentuk motif bangunan. Motif tersebut mengambil inspirasi bentuk bangunan candi yang berciri khas arsitektur bangunan Hindu-Buddha. Bentuk candi mengalami stilasi bentuk dan digunakan sebagai motif pelengkap. Ide penciptaan bentuk motif tersebut mengambil konsep bentuk candi-candi sebelumnya. Adapun bentuk motif tersebut serupa dengan bentuk Candi Badut yang dibangun pada tahun 760 M. Selain itu juga serupa dengan bentuk Candi Jawi yang didirikan kerajaan Singosari pada abad ke 13 M, Candi Penataran (Candi Induk) yang didirikan oleh kerajaan Kediri pada tahun 1194 M, kemudian pembangunan setelahnya dilanjutkan oleh kerajaan Singosari dan Majapahit. Bangunan candi-candi tersebut sudah ada jauh sebelum didirikan Candi Tegawangi pada tahun 1400 M. Fenomena tersebut menjadikan bentuk candicandi sebelumnya yang berciri khas bangunan Hindu-Buddha digunakan sebagai ide penciptaan motif benda teknologis pada salah satu panel yang ada di Candi Tegawangi. Fungsi normatif dalam motif ragam hias tersebut menyimbolkan bangunan suci (tempat pemujaan manusia kepada para Dewa-Dewi).

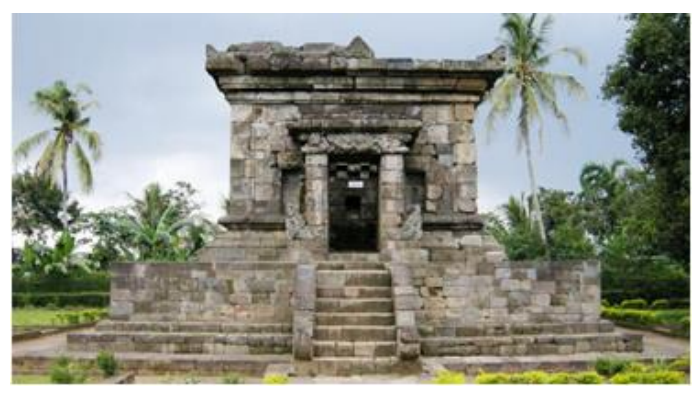

Gambar 4. Candi Badut

Sumber: http://1.bp.blogspot.com/-aHF_3BrudIE/ViW8ONYX5-

I/AAAAAAAAAOE/zvfu3UInzOo/s320/Candi\%2BBadut.jpg 


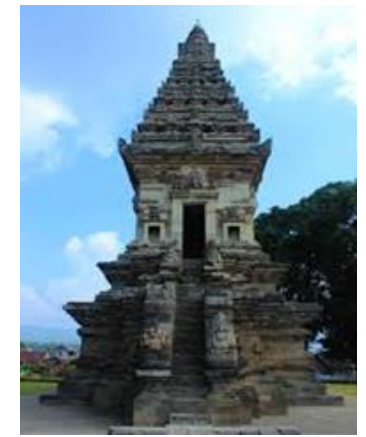

Gambar 5. Candi Jawi

Sumber Gambar: https://encrypted-

tbn0.gstatic.com/images?q=tbn:ANd9GcQu3b9ArMjjRK_tii6BHHTTOpm_eRuzVIzafA\&usqp= CAU

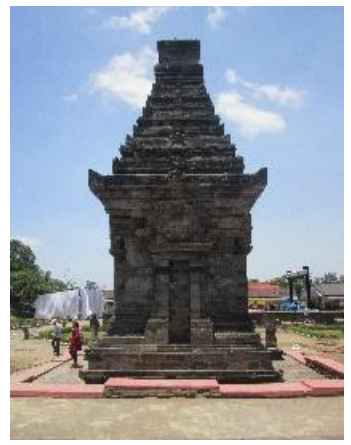

Gambar 6. Candi Penataran

Sumber: Dokumentasi Pribadi 2019

\section{Keserupaan Bentuk Motif}

Kebudayaan di Pulau Jawa merupakan hasil persilangan budaya yang bercampur membentuk budaya baru. Proses pencampuran tersebut membutuhkan waktu yang panjang untuk dapat beradaptasi serta berakulturasi dengan masyarakat lokal (Tjandrasasmita, 2009). Budaya baru tersebut sebagian besar dibawa oleh agama-agama dari luar yang masuk ke Pulau Jawa yang kemudian bersinkretis dengan agama penduduk lokal (Holt, 2000; Lombard, 2008; Sunyoto, 2018).

Agama Hindu dan Buddha yang datang ke Nusantara memengaruhi kepercayaan dan budaya masyarakat Jawa sebelumnya. Pengaruh Hindu-Buddha sangat dominan dan kuat sehingga memunculkan pula sistem-sistem pemerintahan beserta bentuk kehidupan yang bercorak HinduBuddha (Wahyudi \& Jati, 2014). Salah satu pengaruh tersebut memunculkan akulturasi dan sinkrestisme yang bersifat kebendaan berupa bangunan Candi. Candi dan segala unsurnya adalah kebudayaan yang bersifat bendawi (tangible), namun terdapat nilai kebudayaaan didalamnya yang sangat penting sehingga dianggap sebagai kebudayaan tak bendawi (intangible). Bangunan candi merupakan hasil proses adaptasi yang terjadi melalui proses waktu yang lama dan juga melalui proses kreativitas yang tinggi. Proses adaptasi membutuhkan kreativitas, improvisasi, dan konsep karya yang dapat menghidupkan kembali ide-ide yang masih relevan dengan situasi di tengah masyarakat (Nizam et al., 2018).

Setelah Agama Hindu-Buddha telah banyak dipeluk oleh raja-raja dan masyarakat Jawa, Agama Islam kemudian datang ke Nusantara, beradaptasi, berakulturasi dan bersinkretis dengan budaya masyarakat Jawa pemeluk Hindu-Buddha. Seni rupa Islam di Indonesia pada tahap awal 
merupakan hasil penerapan tradisi seni Indonesia-Hindu sesuai dengan fungsi dan kaidah seni baru (Yunus et al., 2012). Salah satu hasil akulturasi dan sinkrestisme tersebut yang bersifat kebendaan berupa bangunan masjid dan makam-makam Islam.

Proses adaptasi, akulturasi dan sinkretisme yang terjadi bukan hanya pada konsep dan bentuk bangunannya saja, melainkan juga pada motif ragam hias yang menempel pada konstruksi bangunannya. Bentuk adaptasi dari motif ragam hias berupa stilasi bentuk (penyederhanaan) dan pengubahan bentuk. Hal ini dilakukan karena adanya tanggapan yang secara konsekuen mengikuti hadits-hadits, yang menjauhi bentuk figuratif baik realistik maupun naturalistis (Yunus et al., 2012). Adapun beberapa faktor yang mempengaruhi terjadinya keserupaan bentuk motif ragam hias yang ada di Candi Tegawangi dan gapura makam Sunan Drajat berupa:

(a) Terjadinya interaksi budaya, interaksi antar budaya memberikan kesempatan kepada individu atau kelompok saling bertukar informasi mengenai budaya dengan individu atau kelompok lainnya yang berbeda budaya. Abad ke 14-15 M terjadi interaksi budaya antara Islam, Hindu, Buddha dan agama Jawa lokal saat itu (Tim Peneliti dan Penyusun Buku Sejarah Sunan Drajat, 1998). Interaksi antar budaya dapat efektif ditandai dengan adanya toleransi, empati, keterbukaan, memahami diri sendiri dan orang lain serta kenyamanan antarpribadi (Delvia \& Putra, 2017). Ketika datang ke Indonesia, Islam tidak menyebabkan revolusi dalam gaya seni bangunan. Malah sebaliknya, arsitektur periode peralihan (abad ke-14 hingga ke-16) mencerminkan gagasan baru. Toleransi Islam dalam menyesuaikan diri dengan kebudayaan setempat mengakibatkan kebudayaan lama tidak mati, tetapi berkembang terus dengan nafas Islam (Yunus et al., 2012). Berlangsungnya interaksi budaya yang efektif pada saat itu membuat adaptasi seni bangunan dan bentuk ragam hias baru muncul.

(b) Terjadinya adaptasi bentuk motif, Linda Hutcheon dalam A Theory of Adaptation mendefinisikan adaptasi sebagai proses menyesuaikan, mengubah, menyocokkan, membuat menjadi sesuai. Adaptasi merupakan pengulangan, namun bukan peniruan dan merujuk kepada tiga hal (Nizam et al., 2018). Pertama, transposisi dari satu karya ke karya lain. Bentuk motif ragam hias pada Candi Tegawangi lebih dikenal dahulu dari pada bentuk motif ragam hias pada gapura kayu Sunan Drajat. Bentuk motif candi dijadikan contoh atau inspirasi dan ditransposisikan ke bentuk motif masjid. Kedua, sebagai proses kreatif yang melibatkan reinterpretasi dan re-kreasi. Terjadi proses kreasi ulang dari bentuk motif candi ke bentuk motif masjid. Bagian atap bentuk motif candi menunjukkan bentuk segitiga yang tidak bertingkat (berundak), sedangkan dalam motif masjid menunjukkan atap segitiga bertingkat (berundak). Bentuk candi terlihat memiliki pintu yang dihiasi dengan ragam hias flora serta bentuk kala pada bagian atas pintunya. Bagian bawah terdapat tangga berundak. Sedangkan pada motif masjid hanya terlihat memiliki lima tiang penyangga yang disela-selanya terdapat bunga lotus. Ketiga, membutuhkan konsep karya yang dapat menghidupkan kembali ide-ide yang masih relevan dengan situasi di tengah masyarakat. Konsep bentuk motif masjid didasari dari tempat beribadah orang Islam berupa masjid. Adanya bangunan masjid disebabkan telah banyaknya masyarakat saat itu yang sudah memeluk Agama Islam. Berubahnya fenomena yang ada di masyarakat saat itu membuat penggambaran rumah ibadah dari bentuk candi yang ditransformasikan ke dalam bentuk dan konsep tempat ibadah masjid.

(c) Terjadinya akulturasi budaya. Akulturasi budaya dapat terjadi jika penduduk lokal lambat laun menerima budaya asing yang masuk. Masyarakat Jawa mempunyai toleransi keagamaan yang sangat besar (Ismawati, 2000). Adanya toleransi yang cukup besar mengakibatkan berlangsungnya akulturasi budaya Hindu-Buddha dengan budaya Islam.

(d) Perkawinan atau terjalinnya hubungan kekeluargaan. Sunan Drajat merupakan putra kedua dari Sunan Ampel dan sekaligus adik dari Sunan Bonang. Sunan Ampel (ayahnya) memperistri putri Tumenggung Wilatikta yang bernama Ni Gede Manila (Gustami, 2007). Adanya 
perkawinan tersebut membuat terbangunnya silsilah keluarga antara keluarga Sunan Drajat dengan kerajaan Majapahit. Hubungan kekeluargaan tersebut menjadikan tanda terjadinya penyatuan dua latar kebudayaan yang berbeda. Salah-satunya berupa penyatuan bentuk motif yang berciri khas Hindu-Buddha dan Islam.

\section{Makna Motif Benda Teknologis}

Motif benda teknologis dari kedua bentuk tersebut termasuk bahasa gambar pictogram. Bahasa gambar pictogram adalah alat komunikasi lewat motif-motif gambar yang masih perlu ditafsirkan kembali pesan yang ada di dalamnya. Untuk mengungkap atau menafsirkan kembali makna dibalik sebuah visual bentuk tersebut digunakan teori semiotika. Adapun dari teori tersebut memaknai sebuah bentuk visual (tanda) dengan makna denotasi (kulit atau bentuk visual) dan makna konotasi (isi). Bentuk ukiran relief motif benda teknologis pada gapura kayu Sunan Drajat berbentuk tempat ibadah (masjid). Makna denotasi dari bentuk visual ukiran relief tersebut merupakan sebuah bangunan masjid yang disangga oleh empat tiang, yang dalam celah-celah tiangnya diisi dengan lima bunga lotus yang mekar. Bagian atapnya berbentuk dua segitiga yang bertumpuk (berundak) dengan bagian atas lancip, yang khas dengan bentuk bangunan masjid yang ada di Jawa. Makna konotasinya berupa rumah tempat ibadah (tempat kesucian) sebagai hubungan vertikal antara manusia dengan Allah (sang pencipta) (Dasy, 2017).

Bentuk pahatan relief pada Candi Tegawangi menunjukkan visual bentuk candi dengan beberapa bentuk figur disampingnya. Makna denotasi yang tampak dari bentuk visual reliefnya berupa bangunan candi yang mempunyai bentuk persegi dengan atap segitiga. Motif kala pada bagian atas pintu bangunan menunjukkan bentuk relief tersebut merupakan sebuah bangunan suci. Kala dalam mitologi Hindu mempunyai fungsi menjaga dan mengusir (menolak) sesuatu hal buruk yang masuk ke dalam tempat suci. Kisah yang ada dalam relief Candi Tegawangi mengisahkan terjadinya beberapa pemujaan, pertama Dewi Kunti untuk memuja Bathara Durga dan kedua, pemujaan Sadewa kepada Dewi Uma atau Parwati. Pemujaan tersebut disimbolkan dengan penggambaran motif bangunan candi. Adapun makna konotasi yang dikaitkan dengan alasan tersebut memiliki makna berupa tempat pemujaan (hubungan vertikal antara manusia dengan Dewa atau Dewi). Makna dari kedua bentuk motif benda teknologis tersebut menyimbolkan bangunan suci. Bentuk motif tersebut hadir untuk mengingatkan manusia akan hubungan manusia dengan yang transenden (Sang Pencipta). Membangun hubungan yang baik dengan sang pencipta akan mendatangkan ketentraman dan kedamaian dalam kehidupan bermasyarakat.

\section{KESIMPULAN DAN SARAN}

Ide penciptaan motif benda teknologis pada gapura kayu makam Sunan Drajat dan Candi Tegawangi mengambil inspirasi bentuk dari bangunan suci yang telah dibangun sebelumnya. Motif benda teknologis pada gapura kayu Sunan Drajat berbentuk bangunan masjid, sedangkan pada Candi Tegawangi berbentuk bangunan candi. Adapun faktor yang menyebabkan terjadinya kesamaan perupaan bentuk dari kedua motif tersebut yaitu, (a) terjadinya interaksi budaya; (b) terjadinya adaptasi bentuk motif; (c) terjadinya akulturasi budaya; dan (d) terjadinya perkawinan atau terjalinnya hubungan kekeluargaan. Makna dari motif bentuk masjid yaitu hubungan vertikal antara manusia dengan Allah (sang pencipta), sedangkan makna dari bentuk motif candi yaitu hubungan vertikal antara manusia dengan dewa atau dewi.

\section{Ucapan Terima Kasih (Acknowledgment)}

Ucapan terima kasih kami sampaikan kepada bapak Rahmat Dasy yang telah bersedia memberikan informasi terkait dengan sejarah, arsitektur kompleks makam dan makna yang terkandung di dalam motif ragam hias yang ada di kompleks makam Sunan Drajat. 


\section{REFERENSI}

Adwina, R., \& Ginanjar, A. (2019). Identifikasi cerita pada relief naratif di Candi Sukuh. PANALUNGTIK: Jurnal Arkeologi Balai Arkeologi Jawa Barat, 2(1), 1-16. https://doi.org/10.24164/pnk.v2i1.23

Ashadi. (2012). Perkembangan arsitektur mesjid Walisongo di Jawa: Perubahan ruang dan bentuk. NALARs, 11(2), 143-160. https://doi.org/10.24853/nalars.11.2.\%25p

Berger, A. A. (2010). Pengantar semiotika: Tanda-tanda dalam kebudayaan kontemporer. Tiara Wacana.

Delvia, A., \& Putra, D. K. S. (2017). Pengaruh interaksi budaya terhadap hubungan harmonis siswa lintas etnis di SMA Taruna Bakti Bandung. E-Proceeding of Management, 4(3), 30243031.

https://libraryeproceeding.telkomuniversity.ac.id/index.php/management/article/view/5005

Guntur. (2004). Ornamen sebuah pengantar. STSI Press Surakarta.

Gustami, S. (2007). Butir-butir mutiara estetika timur: Ide dasar penciptaan seni kriya Indonesia. Prasista.

Holt, C. (2000). Melacak jejak perkembangan seni di Indonesia. Arti.line.

Ilhaq, M. (2016). Bentuk dan penempatan ornamen pada mesjid Agung Palembang. Jurnal Ekspresi Seni, 17(1), 180-193. http://dx.doi.org/10.26887/ekse.v18i2.91

Ismawati. (2000). Islam dan kebudayaan Jawa: Budaya dan kepercayaan Jawa pra-Islam. Gama Media.

Jung, C. G. (2018). Manusia dan simbol-simbol: Simbolisme dalam agama, mimpi dan mitos (D. Arsya (ed.)). Basabasi.

Koentjaraningrat. (1987). Sejarah teori antropologi. Universitas Indonesia (UI-Press).

Lombard, D. (2008). Nusa jawa: Silang budaya. Gramedia Pustaka Utama.

Kusyanto, M. (2020). Kearifan lokal arsitektur masjid Demakan. Talenta Conference Series: Energy and Engineering (EE), 3(1). https://doi.org/10.32734/ee.v3i1.854

Mulyadi, L. (2018). Makna motif relief dan arca candi Surowono dan candi Tegowangi situs kerajaan Kediri. CV Dream Litera Buana.

Nizam, A., Nugraha, W., \& Gustami, S. P. (2018). Eksistensi ragam hias sulur gelung teratai. Journal of Urban Society's Arts, 5(1), 37-48. https://doi.org/10.24821/jousa.v5i1.2416

Raharjo, T. (2011). Seni kriya dan kerajinan. Program Pascasarjana Institut Seni Indonesia Yogyakarta.

Salam, S. (1974). Sekitar wali sanga. Menara Kudus.

Saraswati, R. S. (2015). Penelusuran hubungan kawasan bersejarah masjid Agung Demak dengan masjid Kadilangu. Jurnal Ilmiah Teknosains, 1(1), 57-68. https://doi.org/10.26877/jitek.v1i1/November.839

Senoprabowo, A., Widya Laksana, D. A., \& Putra, T. P. (2020). Inovasi ornamen masjid Agung Demak untuk motif batik kontemporer khas Demak. Ars: Jurnal Seni Rupa Dan Desain, 23(2), 118-127. https://doi.org/10.24821/ars.v23i2.4097

Sumardjo, J. (2000). Filsafat seni. Penerbit ITB.

Sunaryo, A. (2009). Ornamen nusantara: Kajian khusus tentang ornamen Indonesia. Dahara Prize.

Sunyoto, A. (2018). Atlas Wali Songo. Pustaka IIMaN.

Tim Peneliti dan Penyusun Buku Sejarah Sunan Drajat. (1998). Sejarah sunan drajat dalam jaringan masuknya Islam di Nusantara. PT. Bina Ilmu Surabaya.

Tjandrasasmita, U. (2009). Arkeologi islam nusantara. PT. Gramedia.

Toekio, S. (2000). Mengenal ragam hias Indonesia (Angkasa (ed.)). Penerbit Angkasa.

Wahid, A. (1985, Mei). Merumuskan hubungan ideologi nasional dan agama. Majalah Aula: Risalah Nahdlatul Ulama Jawa Timur, 23-32. 
Wahyudi, D. Y., \& Jati, S. S. (2014). Relief Ari Darma di Candi Jago. Jurnal Sejarah Dan Budaya, 8(2), 137-151. http://dx.doi.org/10.17977/sb.v8i2.4766

Yunus, P. P., Soedarsono, \& Gustami. S. P. (2012). Unsur estetika Islam pada seni hias istana raja Bugis. Jurnal Al- Ulum, 12(1), 35-52. https://www.neliti.com/publications/184358/unsurestetika-islam-pada-seni-hias-istana-raja-bugis 